\title{
Going with the flow and yet controlling the Flow: the Early Life, Education, and Scholarship of Takatsukasa Seigyoku, Current Abbess of Zenkōji's Daihongan Convent
}

\author{
Matthew S. Mitchell
}

Correspondence: matthew. mitchell@duke.edu Graduate Program in Religion Duke University Durham, NC, USA

\begin{abstract}
Takatsukasa Seigyoku (b. 1929) is the current abbess of Daihongan convent, which is one of the two administrative heads of the popular Japanese pilgrimage temple Zenkōji. In this paper, I analyze Takatsukasa's autobiographical materials about her early life, her monastic education, and her scholarly works. Her early life, here defined as the time from her birth until 1979, demonstrates the ways in which she asserted or relaxed control over her life at various times, following her motto "going with the flow and yet controlling the flow." Her education at the Pure Land Nuns' Sectarian School brings to light the ways that women come to embody being a nun. Her scholarship demonstrates the ways that biographical narratives can function to create ideals within the monastic community, while at the same time, they place Takatsukasa's convent and the tradition she is a part of within the larger (mostly male) historic record. I also analyze media accounts about her ordination in 1955. From these accounts we can determine that Japanese society's views about nuns (and laywomen, as well) in mid-century combined elements of medieval understandings of taking the tonsure as a sad event with twentieth-century discourses that defined women's roles to be "good wives and wise mothers." Additionally, we can see how Takatsukasa has reclaimed the narrative of her life through writing autobiographical materials, effectively challenging the interpretations of her life produced in newspapers and magazines.
\end{abstract}

Keywords: Japanese Buddhist nuns, Autobiography, Takatsukasa Seigyoku, Buddhist studies research, Agency

\section{Introduction}

As a farewell present from Suenaga [Masao] I received a piece of calligraphy.... It said "going with the flow and yet controlling the flow." 'Suenaga explained it in the following way. When there are changes in the zeitgeist or your surroundings, don't vacillate. Naturally accept and flow [with those changes], but do not lose yourself. Keep firm faith, and before you know it you will become the agent of that flow, leading its direction.

\section{Springer}


In other words, when you first enter large surroundings, you cannot do things in the way you'd like right away. For instance, in a temple, you must do as is done at the temple. Following the way of your surroundings is also important. Then, when you have acclimated to those surroundings, it is all right to slowly begin to move things in the direction in which you wish to go. Since that time [when he gave the calligraphy to me] I have kept this as my motto. (Takatsukasa 2009, 120-122)

In 2009, Takatsukasa Seigyoku, abbess of the Daihongan convent and one of the administrative heads of the popular pilgrimage temple Zenkōji in Nagano City, Japan, published a book entitled Going with the Flow (Nagare no mama ni), in which she frames her life according to the phrase in the calligraphy given to her by Suenaga. It is a clever framing device: Takatsukasa presents the reader with images of her young self, following her mother's wishes regarding education and marriage, following the flow of the events in her life until they led naturally to Daihongan. She also presents the reader with moments where she directed the flow of events by taking or turning down opportunities presented to her, by deciding what was important to her in that moment. In this article I will discuss Takatsukasa's early life, from her birth to 1979. An examination of her life through the frame of the calligraphic phrase given to her by Suenaga provides a way of understanding Takatsukasa's life, and gives the opportunity to examine the agency of one woman within mid-twentieth century Japanese Buddhism and by extension, Japanese society. ${ }^{2}$

For information on Takatsukasa's life, I draw upon the autobiographies that she wrote and dictated in recent years - these appear in book-length form in the aforementioned Going with the Flow and in abbreviated form in the introduction to Living Life in Gratitude (Okagesama no inochi o ikiru, 2011). ${ }^{3}$ Takatsukasa's life story presented in these works is rich and multifaceted, and like all biographies, it is difficult to distill into salient points or provide a singular, overarching narrative. Although these texts offer many points of possible analysis, I have focused on Takatsukasa's path to Buddhism, the representations of nuns in Japanese media, her training as a nun and scholar, and her scholarly works. I have not overwritten Takatsukasa's interpretation of these events; however, I have added some scholarly analysis where necessary. Additionally, I limit my discussion to Takatsukasa's life until 1979. Though seemingly arbitrary, 1979 provides a natural break in her narrative because in that year a fire destroyed much of Daihongan. This caused Takatsukasa to shift her focus from scholarship to engagement in the community.

Following the Introduction, I discuss Takatsukasa's life before she joined Daihongan (Section II). Though she offers much background information regarding her early, preordination life, she also frames it in a certain way - that she largely "went with the flow" and that her life led her to become a nun. At the same time, she indicates that at times she came to "control the flow" when necessary, by making appropriate choices when she could. The story of her decision to join Daihongan is one of these cases.

In section III, I turn to media representations of her biography and ordination. Her ordination in 1955 was covered by a number of newspapers and magazines. The representations in these articles are illustrative of societal views of nuns and nunhood at the time. Many of these articles make reference to an event that happened a few months 
prior to Takatsukasa's ordination, in which a nun at an imperial convent returned to lay life; I also discuss this event as it is useful to understanding their representations of Takatsukasa, and in understanding tropes regarding nunhood at the time. In her autobiographical works Takatsukasa attempts to wrest narrative control of her life from the interpretation provided in these articles.

In section IV I return to Takatsukasa's point of view to discuss her training to be a nun, which she undertook at the Pure Land Sectarian Nuns' School (Jödo shüritsu nishū gakkō). This education was important to Takatsukasa because it was through this training that she learned how to be a nun and perform rituals at Daihongan. According to Takatsukasa, the performance of rituals was one of "the two grass sandals I wore" at Daihongan in the 1960s and 70s. The other grass sandal was her work as a scholar. So, on the one hand (or rather, foot), an examination of her development into a nun able to perform the convent's various rituals allows us to see how education has a formative effect in the embodiment of nunhood. On the other, we can see how her research into and retelling of Daihongan's history, the topic of section V, placed the convent and its abbesses within the larger movements of history, created gender identities (i.e. the ideal form of nun at that convent), and reinforced her place amidst those historic abbesses.

This article discusses biography from several differing points of view and in several different ways. First is Takatsukasa's own biography, which places her own life in historical context (World War II and the postwar period), shapes her preordination life so that it provides the context for her decision to join Daihongan, her training at the Nuns' School, and her decision to write scholarly articles. Next are media representations of Takatsukasa's biography. These strive to understand what type of woman would step outside the roles of wife and mother that were expected of Japanese women in the middle of the twentieth century. At the same time, the authors of these works interpret Takatsukasa's biography so that her life appears different from that of other women, thus providing an explanation for her seemingly odd decision. They also paint her renunciation in a sad light, focusing on the supposed loss of her youth and, by extension, her (re)productive capabilities. Finally, we have Takatsukasa's biographical and historical scholarship, which places the convent and its abbesses in the larger, mostly male-centered histories of Buddhism and society in the early modern (1550-1868) and modern periods (1868-1945). Her biographies of Abbesses Chikan (abbess 1753-1790), Chishō (abbess 1790-1836), and Seien (abbess 1837-1910) also provide several ideals for nuns from Daihongan to follow. ${ }^{4}$

An analysis of Takatsukasa's life provides a number of other important insights. One of the most pertinent is that it offers us a view of nunhood in mid-twentieth century Japan. Although there are a number of works in English and Japanese on medieval nuns, a handful on early modern nuns, and some studies on contemporary nuns, there are few discussions, particularly in English, of nuns and nunhood in mid-twentieth century Japan. ${ }^{5}$ This is unfortunate, because the possibilities available to women changed rapidly in this period. The availability of educational opportunities for women increased following fights for women's education in the 1880s 1920s. Job choices also increased for women following the end of World War II. Additionally, women suddenly gained the constitutionally guaranteed right to vote and to hold political office in 1946. Takatsukasa's life story provides concrete examples of these changes, especially regarding education and work. She attended women's schools through high school, got college degrees, and even completed her master's degree, something that would have been unthinkable before the war. Furthermore, she was able to train at a school specifically for Pure Land nuns, something that would have been unnecessary for most of her predecessors who had taken the 
tonsure at a young age and had trained at the convent under the abbess they would later succeed. $^{6}$

However, despite these changes in the atmosphere, women were still expected to become "good wives and wise mothers," even though this no longer had the weight of official government policy as it had before and during the war. Women's education still largely focused on teaching them to fulfill roles in the household. Even at co-educational schools young women were placed in home economics classes until the 1980s while the same was not required of boys and young men, for instance. Also, although women's employment increased in the postwar period, it functioned largely as a supplement to the income of the household. Young women worked fulltime jobs until they were married or until their first child was born, then returned to work in part-time positions after the birth of their youngest child or after that child had entered school (Uno 1993; Buckley 1993). ${ }^{7}$ Women who stepped outside of the roles of wife, mother, or part-time laborer by remaining in the workplace or to taking the tonsure were seen as anomalies that needed to be explained away or losses that needed to be mourned. The ways that the media discussed Takatsukasa's life and ordination, and that of other nuns as well, in the mid-1950s demonstrates the persistence of these prewar ideals of femininity and how becoming and being a nun meant stepping outside of the expected life course for women of the time.

Her life also demonstrates a change in the way nuns, especially elite nuns, took the tonsure. Takatsukasa chose to join the convent as a twenty-five-year-old woman, while most nuns before her had been sent to convents as girls or teenagers through arrangements between their parents and the abbesses; in some cases, this had happened before the young women were born. ${ }^{8}$ Takatsukasa's ordination as a woman was part of a move away from ordaining young girls, a trend that has continued since the 1950s.

Takatsukasa's life as a nun is also unusual in a number of ways, though these differences can tell us much about the changes and continuities of the time. Takatsukasa came from a high-ranking aristocratic family, and her grandfather had been a duke who served the emperor. Because of this, she had different options available to her than women with "lesser" genealogies. In the premodern, early modern, and to a certain extent prewar periods, women from families such as the Takatsukasa had three options available to them: they could marry, they could join a high-ranking or imperial convent, or they could take on an unmarried role in their natal households or the court (Cogan 2014, 70-71). In the modern and postwar periods, becoming a working woman was also a possibility available to high-ranking women, as Takatsukasa's case demonstrates. However, unlike women from lower-status homes, Takatsukasa was able to join Daihongan and become its abbess because of her family's pre-war status: Daihongan's abbesses have come from high-ranking warrior or courtier families since at least the late seventeenth-century. ${ }^{9}$ The continuation of these limitations and possibilities is telling of the ways that systems such as the court, imperial convents, and the modern aristocracy retained importance after World War II, even though the emperor was no longer considered to be divine, he had been removed from the political sphere, and the aristocracy had been abolished.

\section{Takatsukasa's Preordination Life} Education, Employment, and Research

Takatsukasa Seigyoku was born Takatsukasa Shigeko in Tokyo in 1929. Her father, Nobutaka (1895-1973), was a scholar of tropical fish who worked for the Imperial 
Household Ministry before becoming head of the Sakai City Aquarium - Japan's first aquarium - in 1938. Her father's brothers were all researchers and scholars as well. The Takatsukasa house is one of the five former regent households (gosekke), which meant that it was one of the highest ranked courtier families in pre-war Japan. The Takatsukasa family is distantly related to the emperor by blood, and more closely related through marriage because one of Shigeko's cousins married the current emperor's sister (see Takatsukasa Seigyoku's Family Tree, Fig. 1). ${ }^{10}$ Shigeko's grandfather was a duke who worked as an aide to the Meiji Emperor, and her eldest uncle was the chief priest of the Meiji Shrine.

Shigeko's mother, Atsuko, came from the Mizuno family, a former warrior household that had been the heads of the Suruga Shimazu domain in the seventeenth, eighteenth, and nineteenth centuries. The Mizuno family is related to the Tokugawa household, which had ruled Japan from 1603 to 1868. Atsuko was extremely involved in her daughters' educations, even taking her children out of schools that she felt were not providing proper instruction. Since Shigeko's father's family was largely connected with Shintō shrines, most of her contact with Buddhism came through her mother.

Shigeko went to the Girls' Gakushūin School (the Peeresses' School) for elementary school; the Gakushūin was a school for the children of the aristocracy of prewar Japan. She and her family moved to Sakai City, just to the south of Osaka City, in 1938 after her father became head of the Sakai City Aquarium. She attended several schools in the Osaka and Sakai areas until the start of World War II.

At the start of the war with the United States, her middle school stopped offering real instruction and instead made students sew materials for the war effort. Her mother became frustrated with this and sent her back to the Gakushūin Girls' School. However, education at Gakushūin was also hit or miss: classes were regularly cancelled because of air raids, when school was in session the students spent their time assisting with the war effort instead of studying, and the school's buildings were destroyed in the last year of the war. After the war, the school reopened, with classes held in buildings of the Gokokuji Temple. Following graduation, Shigeko attended the Kyoto Prefectural Women's Vocational School (precursor to Kyoto Prefectural University), where, at her mother's urging, she joined the clothing department so she could gain a skill. Though she did not excel at sewing, Shigeko showed an interest in fashion history when she took a course on the topic from Ema Tsutomu (1884-1979), a professor specializing in the history of manners and customs who guest lectured there once a week.

Ema offered Shigeko a job as an assistant at Osaka City Women's Special School after she graduated in 1949. When she was not assisting Ema with his research or lectures,

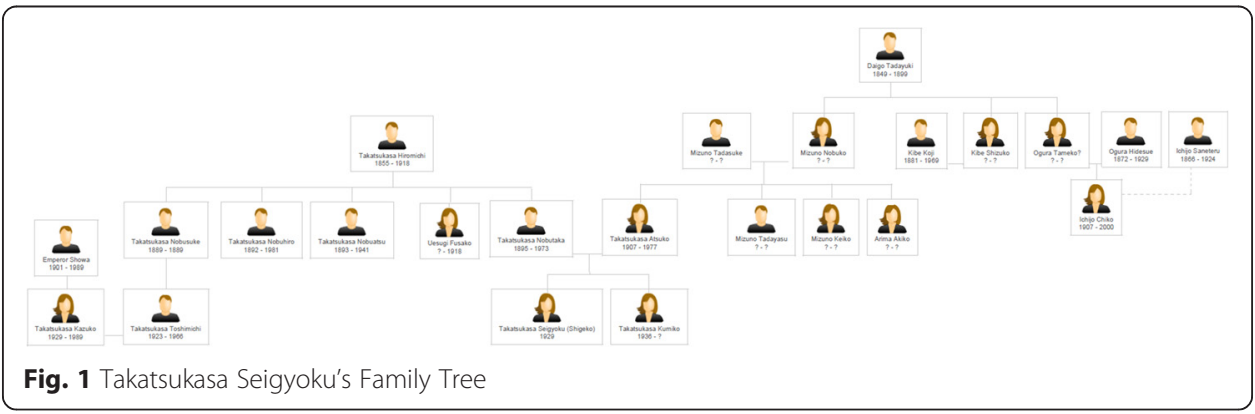


Shigeko could pursue her own research interests, in this case, the ritual clothing worn by courtiers and warriors. In 1951, however, the university system was restructured and Osaka City Women's Vocational School became a part of Osaka City University. Shigeko worried that she might not be able to keep her job as assistant, because with restructuring her degree had become the equivalent of a high school diploma. Because of this, Shigeko began taking courses in Japanese history from Keiō University. She was excited to continue with her education in part because she wanted to make up for the opportunities she had missed because of the war.

During her time at Osaka City University, Shigeko began studying karakumi and hirao, which were intricately woven sashes worn by high-ranking courtiers. She used her contacts to meet the last living artisan making these sashes, Fukami Jūsuke (1885-1974). She visited Fukami's workshop almost every weekend, conducting an oral history of the topic by sketching his designs and recording his stories. In this process, Fukami began teaching her how to weave. He offered to make her his apprentice, but by this time she had already decided to take the tonsure and join Daihongan. While at Daihongan, Takatsukasa published her research into these sashes; she presented this colorful book, Karakumi hirao to Fukami in 1972, a few years before his death.

Though many of her classmates from Kyoto Prefectural Women's Vocational School married soon after graduation, Shigeko was not interested in marriage. She says that she did not want to end up as a strict mother like hers, even though Takatsukasa respected her mother. When the subject of an arranged marriage was brought up, Shigeko said to her mother "I'll do what you think is best." Her mother replied, "you can't do the housework expected of you if you get married." This made Shigeko realize that she was not ready to be married. Takatsukasa later interprets this exchange not as her mother pushing her to learn how to perform household tasks such as cooking, cleaning, and caring for a child, but rather her unwillingness to have her daughter leave the house as a bride. In any case, from that point on, Shigeko met all discussion of marriage from various people with the answer "I'm not ready to be a wife" (2009, 75-76).

\section{Connections with Buddhism, or, the road to Daihongan}

Shigeko's first connection with Buddhism came when she was in elementary school in Sakai. Her mother took Shigeko to visit Shigeko's great aunt, Kibe Shizuko, who was the wife of the head priest at the True Pure Land (Jödo shinshī) temple Kinshokuji near the shores of Lake Biwa in Shiga Prefecture. Kinshokuji was one of the head temples of the Nishihonganji branch of the True Pure Land school, and was a training temple at that time, so it was a center of activity with a number of priests in training in residence during Shigeko's visits. She was fascinated by the temple lifestyle, especially since the Takatsukasa family had closer connections with Shintō than Buddhism. She began to visit for weeks at a time during school breaks; she recounts the dazzling colors of robes of the priests bustling up and down the halls as she helped her great aunt serve and bring back the Buddha's food in the mornings. Her experiences at Kinshokuji paved the way for her eventual decision to join Daihongan. She states that "although I did not understand Buddhist theories, [when I] went to Kinshokuji the feeling of a Buddhist temple came to appeal to me on an emotional level, so the catalyst for my path to Zenkōji was in reality created by my mother, I think" $(2009,40)$. 
Many years later, when Takatsukasa was attending Keiō University, she studied Japanese history. At that time she began to feel that in order to better understand Japanese history she needed to study the history of Japanese Buddhism. Also around that time, Shigeko began working with Suenaga Masao, a professor of archaeology at Kansai University who also lectured at Osaka City University. Suenaga took Shigeko to dig sites, and as part of her work, she participated in surveys of old houses and of the handwritten documents in those houses. In the early 1950s Suenaga was doing a survey of the imperial convent Enshōji's historical documents, in particular the records relating to its seventeenthcentury founder, Abbess Bunchi (1619-1697). He took Shigeko along with him on his trips to the convent. She transcribed the convent's documents, discovering along the way that Bunchi had been briefly married to someone from the Takatsukasa household before she took the tonsure. ${ }^{11}$ When she discovered this, she felt a form of karmic connection with the convent, she reflects later. Shigeko also got a taste for life in a convent: rather than travel to and from Sakai every day, she and Suenaga stayed in rooms in the convent. Taking in this atmosphere was another catalyst in her decision to join Daihongan, she later said. After her ordination, Suenaga mentioned to Takatsukasa that he thought she might consider joining Enshōji; Takatsukasa says that it might have been his main reason for inviting her to join him in the survey (2009, 95-96).

Her connection with Daihongan was again through her mother. After the war, Shigeko's eldest paternal uncle became the general representative (tōri) of the Association of Shintō Shrines (Jinja honchō). His wife became the head of the Women's All Japan Shintō Reverence Association (Zenkoku keishin fujinkai). Because of these familial connections, Shigeko's mother Atsuko was placed in charge of forming an Osaka branch of the Women's Shintō Reverence Association. Their activities included traveling to various shrines, making offerings, cleaning shrine grounds, and so on. Often they would combine travel to distant shrines with sightseeing. Shigeko accompanied them on several trips. On one occasion, they stopped at Zenkōji temple in Nagano City. At that time Atsuko's cousin, Ichijō Chikō, was the vice abbess of Daihongan. Atsuko was able to meet with Ichijō during her visit. On their way home, Atsuko told Shigeko about her conversation with Ichijō. She mentioned to Shigeko, simply as a part of her tale and with no ulterior motive (Takatsukasa states), that Daihongan was looking for a successor. Shigeko turned to her mother and said "if I would be ok [for the post], could I go [to join Daihongan]?" (2009, 103-104)

Takatsukasa reflects in her autobiography that this chance to join the convent was much more appealing to her for some reason than talks of marriage had been. Furthermore, her decision to join Daihongan "felt like it was [the result of] a natural flow of events" for her $(2009,104)$. These events began with visits to Kinshokuji in elementary school which "remained in her mind's eye to an unusual degree," included her discovery at Keiō University of the importance of Buddhism to understanding Japanese history, and, finally, extended through her connections with Enshōji, a convent she had stayed at, transcribed documents from, and had a historical connection with through Bunchi and her short-lived marriage (ibid.).

In any case, Shigeko's declaration initially shocked her mother, but she quickly began laying the groundwork for Shigeko to join the convent. Her father seemed to be against Shigeko going to the convent, though he did not directly tell her about his feelings. In any case, Atsuko eventually changed his mind. Shigeko had second thoughts about her 
decision over the next few months - she was concerned about her ability to give sermons, write beautiful calligraphy, and so on. Each time she expressed doubts, however, an administrator from Daihongan made the long trip from the convent to the Takatsukasa home in Sakai City to assuage her fears. "No, you don't have to give sermons if you don't want to. We have other people who can do that" (2009, 108-109).

Following her graduation from Keiō in 1955, Takatsukasa made preparations and traveled to Zenkōji with her family and Suenaga. She was met at Nagano Station by a crowd of over 10,000 people, and her ordination was attended by family, friends, temple staff, parishioners, and members of the media. She took the tonsure and received her dharma name, Seigyoku, from Abbess Ömiya. She would go on to become the vice abbess in 1959, and the 121st abbess of Daihongan in 1997, a post that she still holds. Her life and ordination were also the subject of several newspaper and magazine articles in 1954 and 1955, since there had been concerns over who would replace the aging abbess. I discuss the media's treatment of Takatsukasa's life and ordination next.

\section{Media Coverage of Nuns}

Coverage of Shigeko's life story and her decision to take the tonsure by the authors of newspaper and magazine articles in the 1950s differed from that presented by Takatsukasa in 2009. One point of discussion was her age. Takatsukasa was in her twenties, while previous nuns had largely been chosen and sent to live at convents as young girls. Thus, many authors of newspaper and magazine articles sought to understand what type of woman would choose to join a convent at this age. Some also focused on how Takatsukasa was choosing to throw away her "life as a young lady." Media discourse surrounding her tonsure provides a window into popular conceptions of nuns and nunhood in the 1950s because of the interpretation of her choices.

An incident that happened just months before Takatsukasa's ordination served as the backdrop for the media's presentation of Takatsukasa. On the night of November 9, 1954 the young woman who was to be head of the imperial convent Chūgūji, Ichijō Sonshō (b. 1919) ran away from her convent. ${ }^{12}$ She traveled to her sister's house in Kumamoto, and from there announced that she was returning to lay life and taking her former name of Hiramatsu Akiko. It later came to light that Hiramatsu, at that time thirty five years old, had fallen in love with a college-aged student of hers at the small flower arranging and tea ceremony school run out of the convent. Her story made the national news (Asahi Shimbun Nov. 25, 1954, morning ed., pg. 7).

The aftermath of Hiramatsu's return to lay status was featured in the Asahi Shimbun newspaper's famed editorial column Tensei Jingo (Vox Populi, Vox Dei) on November 28. The author, presumably Aragaki Hideo (1903-1989), argued that Hiramatsu's plight was not unexpected. He stated that though she may have run away because of love, the responsibilities of managing a convent like Chūgūji may have been too much for her:

Even if love had found its way into the cracks of her quivering heart, she probably could not face the physical and mental responsibilities [of Buddhist life] so she left the convent. Rather than actively looking for a new life, [Hiramatsu] might have run from the complex hardships facing her; she might have sought a break (Nov. 28, 1954, morning ed., front page). 
Convents like Chūgūji had a responsibility to uphold their traditions and maintain their cultural treasures, and the nuns felt the pressure to do so, Aragaki stated. However, the convent had little to no income after World War II: its agricultural lands had been appropriated in the land reforms, and the Imperial Household Ministry, which had regularly given the convent money, ceased to do so in the postwar period. Furthermore, despite being famous for its image of Maitreya from the sixth or seventh century, Chūgūji could not count on income from tourism. So, Chūgūji's nuns had to turn to teaching traditional arts in order to live and maintain their convent. Aragaki argued that this pressure on Hiramatsu would have been particularly difficult since she did not choose to join the convent. Rather, she had been sent to the convent when she was four years old, "much like a little bird locked into the cage of a Buddhist life" by the convent's "strict precepts and fastidious formalities" (Ibid.). In the end he argued that "even if she made a mistake, we should forgive it" (Ibid.). It is unclear how many people sided with Aragaki, but at least one person wrote in to the Asahi supporting Hiramatsu's decision (Asahi Shimbun, Dec. 4, 1954, morning ed., pg. 3).

Media coverage of Hiramatsu did not end there, however. Seven months later, first the Yomiuri Shimbun (June 16, 1955, morning ed., pg. 7) and then the Asahi Shimbun (June 30, 1955, morning ed., pg. 3) newspapers wrote follow up pieces about Hiramatsu's new life with her fiancé, Nakagawa Hiroshi (dates unknown). The authors of these articles seem to be implicitly arguing for married life and against renunciation. They pointed out Hiramatsu's "newlywed glow" (even though she was not yet married), her colorful yukata robe, and her light makeup. They also focused on Hiramatsu's struggle to become a good wife, learning how to cook meals from her soon-to-be mother-in-law and having to be taught about different types and grades of seafood from the neighborhood fishmongers.

Hiramatsu's story was still fresh in the minds of those reporting on Takatsukasa Shigeko's decision to join Daihongan. While to some it may have seemed better that an adult woman would chose to join the convent rather than be sent to one at a young age, the authors still seemed surprised that a young woman who was already a fullyfledged member of society (shakaijin) would choose to take the tonsure. One short biographical article in the Feb. 15, 1955 morning edition of the Asahi Shimbun began by touching upon the Chūgūji incident. It stated that the Takatsukasa household had discussed it, but according to her father, Shigeko had deeply considered joining Daihongan for three years, so it was not a spur of the moment decision.

After covering this, the article moves on to describe Shigeko, though it seems that the author is trying to understand and explain what type of young woman would decide on her own to take the tonsure. He says:

When looking for a trace of the present times in Shigeko, one only finds her permanent wave hairstyle. After graduating from Gakushūin, she attended Kyoto Prefectural Women's Vocational School where she studied clothing, immersing herself in researching the clothing styles of nobles in the late-sixteenth century. Her own taste in clothing is plain, to the point of being old-fashioned. After graduating she began working as an assistant at Osaka City University, where she continues with her studies.... Her father ... is a well-known researcher [of salt-water fish]. It seems that a propensity for research runs in the family: Shigeko loves to study so much that her reading lamp is often on until two o'clock in the morning. (evening ed., pg. 3) 
The author paints an image of Shigeko as different. First, the author removes her from the present age: she has an interest in old clothing, her manner of dress is oldfashioned, and she attended a school for children of the old aristocratic families instead of a public school. Her permed hair is the only marker of her place in contemporary society. Second, the author focuses on Shigeko's studies: she loves to read and study, and her object of study is historical in nature and slightly odd. To this author, a 1950s woman who would choose to join a convent instead of entering into a marriage must be strange and out of touch with the times.

The Asahi Graph magazine featured a picture of Shigeko preparing to leave home on the cover and a four-page spread on her tonsure entitled "Looking for Spring in the Pure Land" in its April 13, 1955 issue. The author begins by describing Takatsukasa's ordination:

The soft song of the Buddha. Accompanied by the plaintive notes of the bamboo pipes $(s h \bar{o})$, Abbess Ōmiya Chiei of Daihongan began to chant sutras. One could see the gleam of tears in the corners of people's eyes, and one could even hear soft sobbing coming from the gathered crowd of over a hundred people. However, the day's heroine, wearing a long white satin overcoat (uchikake) with her black hair flowing over the back, sat straight as a doll as she received the five precepts. This was the scene yesterday, March 26th, as Takatsukasa Shigeko took the tonsure to become the future abbess (the 121st) of Daihongan, cutting ties with her twenty-five years of lay life, her life as a young lady, as her raven-black hair was cut.

After this, the author discusses the hardships facing the convent:

Daihongan's abbesses are directly succeeded by the vice abbesses. The current abbess, Ōmiya Chiei, is elderly at seventy-one years of age, so the convent had to have a successor for the vice abbess, Ichijō Chikō. Furthermore, it is an ironclad rule that the abbesses of Daihongan are "ladies related to the imperial family." Because of these rules, an appropriate successor is difficult to find. There were two or three candidates, but all of them, sadly, did not work out. Eventually Shigeko, who is from one of the five former regent households, was selected. Even within the Takatsukasa household there was resistance in the beginning: "We didn't raise our daughter with the intention of her becoming a nun!" Because of this, the convent thought it had to begin looking again for a time. However, in response to the convent's request, Shigeko replied "if through the Buddha's compassion I am able to save even a few people who are not blessed..." 13 and so it was decided at the beginning of this year because of Shigeko's will. Following the ceremony, with a rounded head [devoid of hair] Shigeko took the name "Seigyoku," and addressed the faithful [gathered there that day]: "I have entered the convent safely. From now on, I hope to train beside the Buddha to the best of my ability." However, perhaps because the Chūgūji incident was fresh in people's minds, there were whispers of “isn't it unfortunate?" even from amongst the faithful.

Despite being surrounded by photographs of Takatsukasa smiling, both before and after taking the tonsure, the Asahi Graph reporter focuses on the tribulations of the 
convent in finding a successor, overcoming the opposition from within the Takatsukasa household, and the tears of those gathered for the ceremony. (Whether these tears were caused by the moving ceremony, or over the "loss" of a young woman to the convent is left unresolved by the author.) The author highlights the forfeiture of Shigeko's "life as a young lady" (ojōsama no seikatsu), as if joining the convent meant the loss of her youth. And, behind the story of Takatsukasa's ceremony, placed there by the author so no one could miss it, was the specter of the Chūgūji incident and the way one nun left the hardships of monastic life to gain that "newlywed glow." The whispers of "isn't it unfortunate," could easily describe the (potential) shadow that the Chūgūji incident cast upon this bright day. However, in the reporter's interpretation, they seem to point back to the sadness of the supposed loss of Takatsukasa's life as a young lady and her (re)productive life as a working woman, wife, and mother.

Reflecting on this article almost sixty years later, Takatsukasa states that it had elements of an emotional human interest story because at that time it was rare for a woman who was in her twenties to decide to join the convent. She suggests that the comparisons with Hiramatsu were perhaps to point out that "even if people leave, there are some who enter temples" (2009, 110-112). She does take issue with the Asahi Graph piece, however, stating that it implied that she was "throwing her youth away to enter the gates of the Buddhist order." She says that at the time she wanted to reply that "it is not that I'm throwing my youth away to do this. I am gambling with my youth as I leave home. I go believing that the path I am taking is worth this gamble" (2009, 258; 2011, chap. Seishun o toshite shukke). Through moves such as this, we can see Takatsukasa asserting agency, wresting control over the story of her life from reporters. Takatsukasa seems to be arguing that she was not a doll, but rather a woman capable of making a decision on her own and that the decision was a rational one, even if the reporters and other members of society could not understand it.

It is clear that articles such as these reflect society's expectations that women should be wives and mothers. Though various industries were dependent upon women's labor inside and outside the home, and many families relied upon the extra income earned by women working as part-time laborers outside of the home, the terms working woman (shokugyō fujin) and office lady (O.L.) carried negative connotations (Buckley 1993, 348). In a similar way to female laborers, nuns occupied a space outside of the home because they were ritual or cultural experts.

However, there is also something else happening in the writings of these authors. They seem to be expressing the opinion that young women should not become nuns, and that young women becoming nuns is a sad occurrence. We can almost hear the authors saying that nunhood should be reserved for those who have already made their contributions to society. This seems to be a continuation of premodern notions concerning nunhood - that women took the tonsure following the death of their children or husbands, when their husbands left them for other women, or as a means to signify their retirement from sexual and familial duties (Meeks 2010b, 18, 36, 47). Furthermore, as a ritual that removed women from sexual activity and signified their preparedness for death, women's renunciation was an emotional affair in many literary representations from the premodern period (Meeks 2010b). We can see these tropes continuing in the media representations of Hiramatsu Yōko's return to lay life, which they report brought her happiness, and their descriptions of Takatsukasa's ordination, 
which supposedly caused tears in the crowd. In this way, many of the societal ideas of nunhood in the postwar period combined postwar ideals that women's place was in the domestic sphere (or outside the house in limited roles as part-time laborers) with those of classical and medieval Japan that women's renunciation was a sad occasion that was reserved for those who had fulfilled their familial obligations in one way or another.

Of course, not all media accounts of Takatsukasa's renunciation were as overtly emotional. The Yomiuri Shimbun's account from February 13, 1955 discusses Takatsukasa's family, her education, and Daihongan. It also provides a brief quote by her about her motivations: "I have been interested in Buddhism since my studies of Japanese history at Keiō University. I hope to overcome various difficulties and become a better person" (evening ed., pg. 3).

Later discussions of women joining the convent followed this unemotional style. By the time a new successor was chosen at Chūgūji in 1960, this overtly emotional, human-interest style reporting of nuns and women's renunciation in the media seems to have come to an end. When Hinonishi Kōson (b. 1930) took the tonsure to become the successor to the abbess at Chūgūji, the Asahi Shimbun simply reported the news and supplied a brief biography of her (Dec. 2, 1960, morning ed., pg. 11; Mar. 27, 1961, morning ed., pg. 10). This is also the case for contemporary news stories regarding Daihongan's abbesses and vice abbesses: national news reports on these women are brief, factual articles detailing the names and ages of the people involved, where they went to school, and the reason for the succession (death, retirement, etc.) (ex. Yomiuri Shimbun, Apr. 3, 2008, morning ed., pg. 31). ${ }^{14}$

\section{Learning to be a Nun}

For Takatsukasa, becoming a nun was more than just about taking the tonsure. She states that she had to "learn how to be a nun" through her time at the Pure Land Sectarian Nuns' School.

Within a week of Takatsukasa taking the tonsure, the head of the Nuns' School, Teramori Kyōzan, traveled to Daihongan to convince the new nun that she should attend her school. When Takatsukasa replied that she planned to attend Taishō University's graduate program, Teramori countered, stating "I'm not saying that studies are unimportant, however, the faithful will not offer you respect if you only study. In the future you will be in a position of respect for faithful nationwide, so you must at least have the basic training to be a nun" (Takatsukasa 2009, 129). Teramori spent half a day laying out the school's curriculum and convincing Takatsukasa that she should attend. She was successful, and Takatsukasa cancelled her plans at Taishō so she could train at the Nuns' School.

The Pure Land Sectarian Nuns' School was founded in 1887 as a nuns' training school attached to the Pure Land Junior High School in Kyoto. In 1912 it became its own institution with buildings on the grounds of the top head temple of the Pure Land school in Japan, Chion'in. ${ }^{15}$ Until Takatsukasa arrived, it was a three-year training program for young women who had graduated from junior high school. Courses there were taught by Pure Land nuns, teachers, and scholars from Bukkyō University. Enrollment fluctuated throughout the institution's life: it reached a high of eighty students in the 1930s, dipped to the low teens during World War Two, bounced back up to between thirty and fifty students when Takatsukasa attended in the 1950s, but slowly 
dwindled until the school closed its doors in 2006 (Takatsukasa 2009, 134; Teramori, 17; Yomiuri Shimbun Feb. 7, 1933, pg. 4).

The Nuns' School provided its students with the opportunity to partake of the curriculum taught in Japanese high schools at the time - math, science, literature, physical education, and so on - while they studied the rituals, ceremonies, chanting, and sutras that would be helpful to them when they returned to their temples or convents. ${ }^{16}$ Being surrounded by other nuns and nuns-to-be in the classrooms, practice halls, and dormitories created an environment where these young women could learn and embody Buddhist teachings and practices. Previously such education occurred "on the job" as young women were trained at convents where they were to be nuns. This move to training at the Nuns' School thus signifies the importance of women's education, even for nuns, who might normally miss out on general educational opportunities if they were educated solely in the convent.

Women at the Nuns' School awoke at $4 \mathrm{am}$. After putting away their futons and washing their faces, they headed to a small hall for morning services. After this, the women went to the dining hall and said a prayer of thanks and repeated Amitābha's name ten times before eating a light breakfast of rice gruel. Next, they cleaned the school or gathered firewood for an hour and a half. Classes were from 8:30 am to 2:30 pm every day except Sunday. In the afternoon students had free time or took lessons in tea ceremony or flower arranging. They returned to the dormitories for more rituals, bathing, studying, and free time before the lights were turned out at 9:30 pm (Yomiuri Shimbun, May 31, 1951, evening ed., pg. 2).

Takatsukasa's arrival was the opportunity for the school to expand its curriculum, offering courses to women similar to Takatsukasa, who had decided to take the tonsure later in their teens and twenties, after having attended high school or college. Six women joined Takatsukasa in the expanded curriculum that first year. This increase signified a larger change in demographics of women becoming Pure Land nuns, as Takatsukasa's life story demonstrates - from younger, junior high and high school aged women to women in their late teens and twenties who had already completed high school and maybe even college. More work needs to be done to unearth more concrete, less anecdotal evidence of this demographic change, however.

For Takatsukasa, the Nuns' School represented a large shift in her way of life. The school's schedule was not a problem - she had become accustomed to waking up early after only a few days at Daihongan. The curriculum posed no difficulties either, even though she was attending courses both at the Nuns' School and at Bukkyō University. Rather, she had to come to embody "nunhood" through ritual training, physical comportment, and physiological changes. First, she had to learn to perform the daily rituals at the School. For example, she had to learn how to chant, something that neither years of participation in chorus nor observing rituals at Daihongan had prepared her to do. Though she was intimidated by the ritual and chanting proficiency possessed by women half her age, she gradually picked it up. She also had to learn how to act as a nun, or rather, how not to act as a nun. Though the School operated under a version of the Nuns' Vinaya modified to fit a more modern lifestyle, ${ }^{17}$ Takatsukasa still ran into difficulties because some of the things she did without thinking were banned at the School. For example, near the beginning of her time there, she was scolded because she was seen wearing a watch and taking pictures of the city in her free time. Though she 
thought these were regular actions, she was told that carrying worldly items such as a camera or watch "were not things that nuns do" $(2009,137)$. Finally, the daily cleaning, bowing, chanting, and eating caused changes to Takatsukasa's body. In particular, the School's strict vegan diet of rice gruel for breakfast, a bowl of rice, soup, and a vegetable side for lunch and dinner ${ }^{18}$ altered Takatsukasa's body. Although she quickly adjusted to the reduced portion size, she lost a great deal of weight. Within six months of joining the School, Takatsukasa had to receive treatment for malnutrition. She quickly recovered, and had no further problems of this sort, but was told at her regular doctor visits that her bone density had decreased due to this diet. Despite being raised on a modern and lavish diet by Japanese standards at the time that included meat, fish, dairy, and so on, Takatsukasa has largely maintained a vegetarian diet since her time at the Nuns' School.

Though in some ways harsh, her time at the School was formative. Takatsukasa states that through her time at the Nuns' School, she "came to know what it meant to be a nun" $(2009,157)$. She considered the School's place in the education and formation of young nuns' identities to be so great that she offered an as-needed two-year training program for nuns at Daihongan after the Nuns' School closed in 2006. Only a few women have taken part in it, but she maintains that the offer of an education is there when needed.

Scholars have long noted the ways in which joining the nuns' order affected women's femininity, and they have largely focused their attention on the act of taking the tonsure. Bernard Faure states that with the full tonsure a woman symbolically became a monk, "that is, an allegedly genderless being" (Faure 2003, 44). Similarly, Lori Meeks writes that the tonsure represented "a move toward a less feminine, or perhaps asexual identity" for female renunciants (Meeks 2010b, 19). As Meeks notes, however, the tonsure was only the most clearly visible marker of the change in feminine identity - other changes, such as sartorial choices and the adoption of gender-neutral appellations, also "dismantle[d] their female identity" (2010b, 34). Works such as these are extremely helpful in identifying the outward signs of the femininity (or the removal thereof) of Buddhist nuns in Japan's Classical and Medieval periods (500-1550 CE).

I agree that taking the tonsure is and was seen to affect ontological and soteriological changes in a person. ${ }^{19}$ However, as Takatsukasa's time at the Nuns' School indicates, how nuns come to embody a certain type of femininity through education is just as important to their identities as nuns as the singular moment of transformation of taking the tonsure. ${ }^{20}$ As Takatsukasa herself indicates, she came to embody the role of nun (and eventually abbess) through coursework, the repeated performance of Buddhist rituals, and the occasional personal remonstration of her teachers at the Pure Land Sectarian Nuns' School.

\section{Research}

After her two years of schooling at the Nuns' school and Bukkyō University were finished, Takatsukasa stayed in the School's dorms for another two years as she completed a master's degree at Otani University in Chinese Buddhist history. She then returned to Daihongan in 1959 and was named vice abbess. After her return from Kyoto, Takatsukasa began to investigate the historical documents housed at Daihongan. Her scholarly training at Keiō, Bukkyō, and Ōtani Universities, as well as her hands-on 
experience during the survey of the imperial convent Enshōji's documents while she was an assistant to Suenaga Masao in the early 1950s had prepared her to do this. Furthermore, the environment at Daihongan was conducive to her research because "leaving home meant leaving behind the troubles of the secular world" (Takatsukasa 2009, 158). Additionally, there were a number of internal and external motivations for her to do this research. Ichijō, then the vice abbess, requested that she write the convent's history. Later, the editors of the Journal of Bukkyō University (Bukkyō daigaku kenkyū kiyō) asked for some of her research on the convent for their journal. Takatsukasa also felt that it was her "duty as someone who had studied history to piece together [Daihongan's history from] these important documents that had lain dormant" for many years $(2009,158)$.

Takatsukasa's research into Zenkōji, Daihongan, and her predecessors has appeared in a number of formats (Table 1). She has published materials for the Pure Land sect, especially its nuns' group publications, including a piece on Daihongan and its nineteenth-century abbess Seien in the Pure Land School Nuns' History (Jódoshū nisōshi) in 1961. Additionally, she has used her research to create narratives for public consumption. Some of these have been published by Daihongan and can be purchased there. Others have appeared as snippets in her autobiography, Going with the flow.

Finally, she has also published a number of scholarly articles in the Journal of Bukkyo University and a book-length biography of the eighteenth-century Abbess Chikan in the 1960s and 70s. These have had an impact on the scholarly community, and are important because they predate the scholarly focus on nuns and convents that began in the 1980s. ${ }^{21}$ Pure Land historian Tamayama Jogen (b. 1932) praised her work on Abbess Chikan, saying that it "is an important achievement that fills in a blank [in Japanese historiography]. It deserves special mention as a work that pioneers one aspect of early modern [Japanese] Buddhist history" (Tamayama 1976). Furthermore, by presenting the life of Abbess Chikan based on documents Chikan had written, Takatsukasa "allows us to grasp the reality of the early modern Buddhist world and of its convents" ibid.

The majority of her works are written in a straight-forward manner with a historical tone. In her histories of the convent for public consumption she occasionally draws

Table 1 Takatsukasa Seigyoku's major scholarly publications

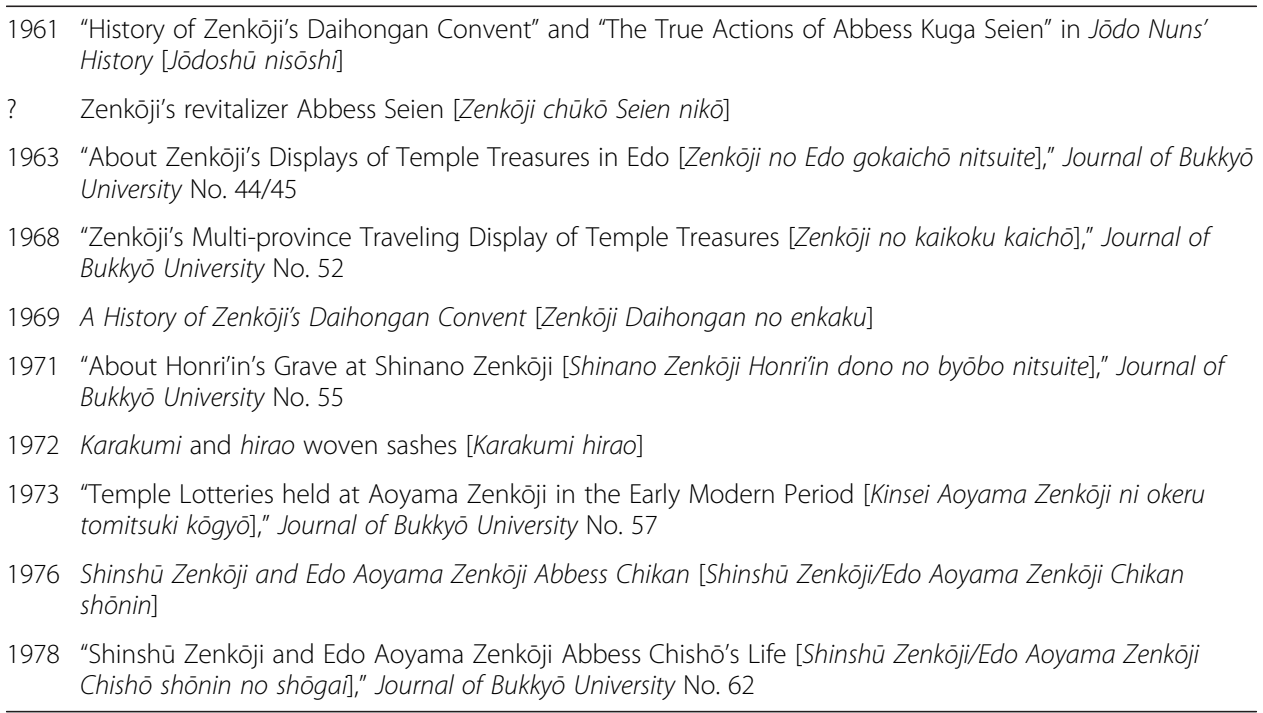


from convent legends; for example, she relates how the founding abbess, Sonkō, supposedly the daughter of one of the initial supporters of Buddhism in Japan, Soga no Umako (551?-626), was ordered by Empress Koggyoku to found a convent to serve the Zenkōji Amitābha image. However, the majority of her works draw from extant documents and convent journals, which is not surprising given her historical training. In these scholarly works she describes the convent's involvement in displays of the convent's Amitābha images or temple lotteries for fundraising. Historical documents also form the basis of her biographies of abbesses Chikan, Chishō, and Seien. These works elucidate the lives of these women, the day-to-day workings of the convent, and its relations with Buddhist and secular institutions and individuals. In her autobiography, Takatsukasa reflects on her research into these women; she states that though Chikan and Chishō were "abbesses who did not do anything especially extraordinary," they "navigated the complex hierarchies" that Daihongan was a part of, adroitly "managing both Daihongan and its branch temples, all the time facing resistance from the monks within Zenkōji's Daikanjin temple. This could not have been easy" (Takatsukasa 2009, 194-195).

Abbess Seien weathered the much more turbulent mid- to late-nineteenth century as Japan modernized. As Takatsukasa recounts Abbess Seien's tale in Going with the Flow, it is clear that she has deep admiration for her. She relates how Seien survived the destruction of both Daihongan and its branch temple in the capital by earthquake, at one point weathering the aftershocks in a bamboo grove with the convent's icon rather than part from it. She states how Seien later petitioned the emperor to prevent Zenkōji temple from becoming the Shintō Zenkō Shrine during the separation of Buddhas and Shintō deities in the 1870s. She also explains how Seien resisted the forced laicization of Buddhist monks and nuns related to the emperor; ${ }^{22}$ Seien supposedly said

You can take away the robes that are wrapped around my body, but there is no way to take those that wrap my heart/mind. The black hair that has been shaved [from my head] with a blade can grow long, but can the shaved hair in my mind ever grow? Once a body has taken vows before the Buddha, it can accept any form of persecution; for this reason, I cannot follow your orders [to laicize]. My body has been offered up for the spread of the recitation of Amitābha's name, as a lifelong follower of the Buddha. (Takatsukasa 1961, 105-106; 2009, 181-183)

Though Seien died forty years before Takatsukasa arrived at Daihongan, those who had met her described her to Takatsukasa as "a living Buddha," one who could convert the minds of the masses simply by chanting the name of Amitābha, she states $(2009,186)$.

Of course, Buddhist biographies are not new: there are various retellings of Shakyamuni's life, the biographies of early Buddhist monks and nuns in the Apadana, and in China and Japan, the genre of tales of eminent monks and nuns was popular as well. These tales of eminent monks and nuns recounted the accomplishments of renunciants, both those who were well-known and those who were not. They were created for a number of reasons - to counter anti-Buddhist images, to create ideal images of monks and nuns, and encourage the sponsorship of Buddhism because their intended audience was the emperor or other wealthy laypeople (Kieschnick 1997; Grant 2009). Monks and nuns writing in later periods could follow this genre's conventions and place 
themselves or others within the ranks of these eminent renunciants (Cogan 2014). Biographies of female founders of convents have not only provided role models for the nuns of the convents, but have also explained why they are worthy of respect by representing these women's good deeds, focusing on their salvific potential instead of their supposed shortcomings as women, and highlighting their connections to bodhisattvas (Meeks 2010a, 260-283, 298-300).

There were several key elements in these tales. They told of the renunciant's parents or famous relatives, her/his birth if it was miraculous, first master or famous teachers, ordination, books (s)he read, things (s)he accomplished, students (s)he taught, and a description of her/his death including signs of auspicious rebirth if any (Kieschnick 1997, 4-5). Takatsukasa's biographical works can be placed within this genre to a certain degree. For example, they include a number of these elements, but as is the case with many modern biographies, they remove any or all reference to miraculous occurrences, and instead focus on the actions of the abbesses and their connections to historical events. Additionally, her biographical materials on the nuns Chikan, Chishō, and Seien are largely chronological. Her biographies of the other abbesses start with negotiations to bring the soon-to-be abbesses into the convent as young girls. These proceed through a number of events in that person's life, and end with their deaths and funerals.

Takatsukasa's scholarly narratives do several things. First, detailing these women's lives filled in a blank in the history of women in early modern Japanese Buddhism as Tamayama noted. They put the convent and its abbesses within the greater context of Japanese history, describing the lives of "nuns who had been revered within the convent" to the outside world (Takatsukasa 2009, 176). They have influenced subsequent histories of early modern Buddhism, Zenkōji, and Nagano City. They allow Takatsukasa to explain her convent to visitors in person and through booklets. And they explain why Daihongan was able to survive the travails of the early modern and modern periods while other similar convents did not.

However, as we well know, explanation is not the only function of narrative. Narrative is a performance; narrative does things, creates things. In this case, Takatsukasa's work reaffirms her place as co-administrator (along with the head monk of the Daikanjin monastery) of Zenkōji. It creates and reinforces ideas of what it means to be a Pure Land nun and an abbess at Daihongan by providing numerous examples from the lives of previous abbesses who "came to gain support and spread faith through their practices" $(2009,171)$; this is similar to the ways that Medieval nuns at Hokkeji convent used narratives of their convent's founder, Empress Kōmyō (701-760) (Meeks 2010a, 260-283). It instilled in Takatsukasa an understanding of the importance of her place within a lineage of "previous abbesses who had protected and passed on [the convent's] practices" to her (Takatsukasa 2009, 254). By incorporating the narratives of these women into her own life story, Takatsukasa defines herself in relation to these previous abbesses for petitioners to Daihongan, both as these abbesses' successor and the historian who unearthed their tales. ${ }^{23}$ At the same time, through her own research and writing, Takatsukasa has created a new model for the next generation of nuns and abbesses to emulate, one in which nuns can wear the "two woven grass slippers" of Buddhist practices and historical research, like Takatsukasa did. 
Unfortunately, however, Takatsukasa says that she lost her desire to do historical research in the wake of a large fire on the convent's grounds in 1979. Though the fire destroyed eleven of the convent's buildings and many of the convent's books and treasures, the nun Tsujita Seijun had the presence of mind in the face of the disaster to close the doors to the fireproof storehouse; many irreplaceable historical records were saved from the conflagration through her quick action (Zenkōji, 160-163).

Since the 1980s, Takatsukasa has replaced her grass sandal of scholarship with one of local, national, and international engagement. Locally, she serves as the head of a Girl Scout troop, espousing Buddhist ideals during meetings. Daihongan also runs a day care for children and an assisted living facility for the elderly. On the national scene, Takatsukasa has been active in training new nuns, as mentioned above. She has served as the vice president of the Yoshimizu kai, the Pure Land sectarian nuns' organization and chair of the Nagano Prefectural branch of the All Japan Buddhist Nuns' Association (Zen Nihon Bukkyō nisō hödan). Internationally, she has traveled extensively to perform Buddhist rituals and participate in meetings. Additionally, Daihongan hosted a Taiwanese nun through a monastic exchange program.

\section{Conclusions}

Takatsukasa's early life demonstrates how agency can vary at different points in a woman's life. As a girl, Takatsukasa largely relinquished control over her education, marriage, and life to her mother. As a young woman, she took control in small ways - focusing on fashion history instead of sewing at the Women's Vocational School, for instance. She also began to take charge when opportunities were presented to her, becoming an assistant when Ema Tsutomu offered her a job following graduation. She came to realize what was important to her through these small choices and opportunities. She decided on her own to attend Keiō University's history department to make up for lost educational opportunities, for instance. By going with the flow and relinquishing control for a time Takatsukasa was able to exert control over her life at appropriate moments. Ultimately, it led her to Daihongan and then became her modis operandi at the convent. Perhaps because of its centrality to her story, Takatsukasa describes going with the flow differently in different sections of the book. At points it is the subservience of a young girl to her mother's wishes. At others, the flow represents karmic connections she has to Buddhism that lead her to encounters with temples, priests, and nuns. In other places she relates going with the flow with relying on the compassion of the Buddha, that it will lead to unsought after benefits, such as her becoming the head of Daihongan. Each of these interpretations works in relation with events she is discussing at the time.

Takatsukasa says that she has been less successful with "controlling the flow." In part, she says, this has to do with "places like Daihongan having such large flows"; though she leaves these flows undefined, they could be traditions at the convent and visitors' expectations (Takatsukasa 2009, 258). She is not daunted by this, however, and continually seeks to direct Daihongan so it can remain relevant to the world and make society a better place:

The environment and social situation I am in are constantly evolving. The Buddhist world and individual temples alike do not exist solely to protect tradition.

Furthermore, I am not [in this convent] only to achieve my own peace of mind, but 
rather to seek peace and harmony for all of society, for all of the world. I believe we can discover something even we nuns can do, making advances little by little (ibid., 259-260).

Much previous scholarship tends to couch women's agency in terms of the western feminist concepts of defiance, subversion, or manipulation of the patriarchy. However, examining agency in Takatsukasa's life allows us to see an emic view of life as a nun and abbess that goes beyond such concepts. It places her choices, whether to go with the flow or to control it, in the context of specific points in her life. It points to the need to consider the complexities of these women's lives and their agency over time along with reference to class and status, both inside and outside of the convent.

Additionally, while the media reports regarding Takatsukasa and Hiramatsu demonstrate the public understanding of nunhood as a loss, we can also see Takatsukasa exerting control over the reports fifty years after they appeared. She provides a corrective lens to the public narrative about her by providing the story of her life leading up to Daihongan - stating her affinity towards Buddhism from an early age and how her decision to join the convent was the natural result of her life events. Takatsukasa also attempts challenge the dominant discourses surrounding nunhood, to transform society's interpretation of joining the convent from a tale of loss - of youth, (re)productive duties, marriage - to one of gain, of joining something that is worth such a decision.

Additionally, Takatsukasa's life story, especially her early years as a nun, provides a wonderful example of how femininities are embodied and deployed in specific contexts. While becoming a nun by taking the tonsure and donning Buddhist robes did alter Takatsukasa's life and femininity in the ways that Faure and Meeks suggest, Takatsukasa's life story demonstrates that being a nun was more than simply a change in hair and clothing. She had to learn to perform rituals and come to embody a particular type of nunhood through her time at the Nuns' School and her study of the lives of Daihongan's abbesses. Her story demonstrates the ways that gender roles are not essential or natural to men and women, monks and nuns, but rather that they are performative; they are learned and deployed; they are context specific and flexible.

Takatsukasa's training helped her be able to embody her role as a nun and abbess and taught her to be able to perform the rites expected of her. Her scholarship helped her and others understand her position within the convent's history and Japanese society. It provided role models for Takatsukasa and other nuns. And it provided material for her sermons to the laity - the sermons she was so worried about doing before she took the tonsure. Through going with the flow and yet controlling the flow, training at the Nuns' School, and her own research, Takatsukasa came to embody the role of a respected abbess of a famous temple.

\section{Endnotes}

${ }^{1}$ It says 随流而制流, which Takatsukasa translates into Japanese as "Nagare ni shitagatte, shikamo nagare o sei su," or "going with the flow and yet controlling the flow." The phrase as a whole does not appear in Chinese or Japanese literature. However, the first half appears in Sima Qian's Shiji (Historical Records) under the biography of Sima Xiangru where it says "to follow the flow and yet transform" and "to follow the flow and 
yet repel." The second half of the phrase appears in the Sunzi bingfa (Master Sun's Art of War), as "Military strategy is like water.... Water adapts to the ground and so controls its flow." See the (Chinese Text Project database http://ctext.org/pre-qin-andhan). Thanks to John Tucker at Eastern Carolina University for assistance with this and for translation of these passages.

${ }^{2}$ Scholars have long debated questions regarding the agency of women in patriarchal religious traditions. Recent scholarship has attempted to reassess western scholarly assumptions regarding women, agency, resistance, and religious traditions. For example, Dorothy Ko describes women's roles in transmitting Confucian discourses and their interests in doing so (Ko 1994; Ko 2005). Saba Mahmood reevaluates the relationship between agency and resistance, highlighting how women in Islamic piety movements in Egypt may have expressed their agency through the adoption of certain values specific to their tradition (Mahmood 2012). Until a few years ago, scholarship on women in Japanese Buddhism took one of two approaches with regards to these issues. In the first, scholars viewed women participating in these traditions in a sad light: they were repressed by patriarchal society outside and androcentric doctrines inside the convent. Women were thus stripped of all agency whether they entered a convent or not. In the second, scholars viewed convents as a means for women to escape the repression that they faced from broader society; thus they were liberating spaces where women could gain agency. Recent works have attempted to move beyond this debate by accepting that although convents did transmit patriarchal ideologies, they also provided tools for women to maneuver through them (Meeks 2010a, 9-14; Cogan 2014, 16-20). I follow the model set by these recent works, which we can see in Takatsukasa's life: she faced androcentric doctrines and ideals from Japanese society, and yet she was also able to circumvent and attempt to alter those through her scholarship and autobiography.

${ }^{3}$ This title could also be translated as Living Life [that I have] Gratefully Received, but Living Life in Gratitude has the benefit of not having pronouns, so it retains the ambiguity of the Japanese title where it is not clear who is doing the living. Thanks go to Barbara Ambros at the University of North Carolina at Chapel Hill for offering this wonderful suggestion.

${ }^{4}$ For more on Buddhist women's autobiographical and biographical writings, see (Jacoby 2014).

${ }^{5}$ One exception to this is Chapter Three of Paula Arai's Women Living Zen (1999), which chronicles the lives and work of several Sōtō nuns from the early twentieth century to the late 1990s. This chapter of Arai's book is largely focused on the struggle of these women to seek recognition and equality within the Sōtō Zen sect. This article, on the other hand, is more focused on the life and education of Takatsukasa, on media representations of nuns during the 1950s, and of her scholarly work and the way it places her convent within history.

${ }^{6}$ One exception to this is Seigyoku's predecessor, Ichijō Chikō, who had also studied at the Pure Land Sectarian Nuns' School. Unfortunately, however, there is not much information regarding Abbess Ichijō's life or her time at the Nuns' School.

${ }^{7}$ This trend continues to the present day. For more, see (The Economist 2014) 
${ }^{8}$ One prominent example of a high-ranking nun taking the tonsure and joining (or in this case founding) an imperial convent is the seventeenth-century nun Bunchi. For more on her life, see (Cogan 2014; Fister 2000)

${ }^{9}$ According to the convent, this tradition of abbesses coming from high-ranking families goes back to Abbess Sonkō, who supposedly founded the convent in the seventh century. I have not been able to find historical documents discussing the natal families of abbesses prior to Chizen (abbess 1698-1727), however.

${ }^{10}$ Takatsukasa Seigyoku's Family tree is an abbreviated version of the one that appears in (Takatsukasa 2009, 4-5)

${ }^{11}$ For more on Bunchi's marriage and renunciation, see (Cogan 2014)

${ }^{12}$ Though both Ichijō Sonshō and Ichijō Chikō, Takatsukasa Seigyoku's predecessor at Daihongan, have the family name of "Ichijo," they were not related by blood. Instead, they were adopted into the Ichijō family. Ichijō Chikō of Daihongan was adopted by Ichijō Saneteru (1866-1924), and Ichijō Sonshō of Chūgūji was adopted by Ichijō Sanetaka (1880-1959). Sanetaka was Saneteru's son-in-law and adopted son. It was relatively common practice for young women to be adopted into courtier families so they could take over positions at high-ranking and imperial convents.

${ }^{13}$ Ellipses in original.

${ }^{14}$ This perhaps represents a change in the ways the national media reported on nuns rather than a change in the ways that Japanese society viewed nuns. Katsumoto Karen (b. 1955), a scholar and a Tendai nun, notes that contemporary societal views of nuns have not changed, and many still consider nunhood to be a sad thing signifying old age, or, if the nun is younger, that she is escaping from a bad relationship or mourning the death of her husband (Katsumoto 2012, preface).

${ }^{15}$ For more information on the founding and transformations of the Pure Land Sectarian Nuns' School, see (Jōdoshū nisōshi hensan iinkai 1961, 295-305). Other Buddhist sects also developed training schools. For more on the nuns' schools of the Sōtō Zen sect, especially their founding and the ways that nuns' education was a means to combat gender discrimination within the Sōtō sect, see (Arai 1999, chap. three).

${ }^{16}$ Shortly after Takatsukasa's time at the Nuns' School, it gained official recognition by the Ministry of Education, Science, and Culture. The high school portion was named Yoshimizu High School 吉水高等学校. The school regulations for both the High School and the Special Course, as they were submitted to the Ministry, are in (Jódosh $\bar{u}$ nisoshi hensan iinkai 1961, 295-305). These regulations cover the goal of the courses, attendance policy, etc. They only include general rules for comportment, such as "students should not engage in sexual activity" or "students should not disrupt the school's atmosphere."

${ }^{17}$ The Yomiuri article "Amasan no gakkō" discusses this, but does not mention how exactly many of the rules were changed. (Yomiuri Shimbun, May 31, 1951, evening ed., pg. 2)

${ }^{18}$ Dinner was called “medicine” (yakuseki 薬石 or kusuri 薬) at the Nuns' School.

${ }^{19}$ For example, Gina Cogan discusses how Bunchi, founder of Enshōji, chose the Bodhisattva precepts over other precepts when she built an ordination platform because she felt that these precepts could change a person so he or she would be able to become enlightened. (Cogan 2014, chap. 9) 
${ }^{20}$ See David Morgan's Introduction to Religion and Material Culture: The Matter of Belief for more on how religions are felt, embodied, etc. as much as they are creeds that are learned (Morgan 2010). This is based on the assumption that gender identities are certainly not fixed, so what it meant to be a fully ordained nun varied at different points in history, locations (geographical and within hierarchies), and contexts. See Gina Cogan's and Oka Yoshiko's work on Enshōji in the early modern period for more on the varying roles and expectations for nuns in different positions within the convent's hierarchy (Cogan 2014, chap. 8; Oka 2009, 69-73).

${ }^{21}$ As Gina Cogan notes, prior to the 1980s, there was little work done on nuns or convents; scholarship that did appear was on individual convents or groups of nuns, such as the sectarian works Sōtōshū nisōshi or Jōdoshū nisōshi. A number of works on women in Buddhism began to appear in the 1980s, spurred on by the formation of the Research Group on Women and Buddhism in Japan by Nishiguchi Junko and Ōsumi Kazuo. (Cogan 2014, 5-6; Ōsumi 2002)

${ }^{22}$ For more on this and how other imperial abbesses handled the transition, see (Cogan 2006).

${ }^{23}$ For more on "relational selfhood" in Buddhist women's biographies, see (Jacoby 2014, 12-14).

Competing interests

The author declares that he has no competing interests.

Received: 31 March 2015 Accepted: 29 January 2016

Published online: 06 February 2016

References

Arai, Paula Kane Robinson. 1999. Women living Zen: Japanese Sōtō Buddhist nuns. New York: Oxford University Press. Asahi Shimbun Newspaper and Asahi Graph Magazine. Retrieved from Kikuzō II Bijuaru for Libraries: Asahi Shinbun kiji database, Asahi shinbunsha.

Buckley, Sandra. 1993. Altered states: The body politics of 'being-woman. In Postwar Japan as history, ed. Andrew Gordon, 347-372. Berkeley: University of California Press.

Chinese Text Project database. http://ctext.org/pre-qin-and-han Accessed 10 March 2015.

Cogan, Gina. 2006. Time capsules for tradition: Repositioning imperial convents for the Meiji period. U.S.-Japan Women's Journal English Supplement 30-31: 80-104.

Cogan, Gina. 2014. The princess nun: Bunchi, Buddhist reform, and gender in early Edo Japan. Cambridge, MA: Harvard University Asia Center.

Faure, Bernard. 2003. The power of denial: Buddhism, purity, and gender. Princeton, NJ: Princeton University Press.

Fister, Patricia. 2000. Creating devotional art with body fragments: The Buddhist nun Bunchi and her father, Emperor Gomizuno-o. Japanese Journal of Religious Studies 27(3/4): 213-238.

Grant, Beata. 2009. Eminent nuns: Women Chan masters of seventeenth-century China. Honolulu: University of Hawai'i Press.

Jacoby, Sarah H. 2014. Love and Liberation: Autobiographical Writings of the Tibetan Buddhist Visionary Sera Khandro. New York: Columbia University Press.

Jōdoshū nisōshi hensan iinkai (Eds.). 1961. Jōdoshū nisōshi. Kyoto: Yoshimuzu Gakuen Kōtō Gakkō.

Katsumoto Karen. 2012. Amasan wa tsuraiyo. Tokyo: Shinchosha.

Kieschnick, John. 1997. The eminent monk: Buddhist ideals in medieval Chinese hagiography. Honolulu: University of Hawai'i Press

Ko, Dorothy. 1994. Teachers of the inner chambers: women and culture in seventeenth-century China. Stanford: Stanford University Press.

Ko, Dorothy. 2005. Cinderella's sisters: A revisionist history of footbinding. Berkeley: University of California Press.

Mahmood, Saba. 2012. Politics of piety: The Islamic revival and the feminist subject. Princeton, NJ: Princeton University Press.

Meeks, Lori Rachelle. 2010a. Hokkeji and the reemergence of female monastic orders in premodern Japan. Honolulu: University of Hawai'i Press.

Meeks, Lori Rachelle. 2010b. Buddhist renunciation and the female lifecycle: Understanding nunhood in Heian and Kamakura Japan. Harvard Journal of Asiatic Studies 70(1): 1-59.

Morgan, David. 2010. Introduction: The Matter of Belief. In Religion and material culture: The matter of belief, ed. David Morgan, 1-18. New York: Routledge.

Oka Yoshiko (ed.). 2009. Nihon no sh kyō to jenda- ni kansuru kokusai sōgō kenky : amadera chōsa no seika o kiso to shite. I. Honbunhen. Nishinomiya: Okayoshiko.

sumi Kazuo. 2002. Forward: A new age of research on women and Buddhism. (trans. Barbara Ruch). In engendering faith: Women and Buddhism in premodern Japan, ed. Barbara Ruch, xxiii - xxvii. Ann Arbor, Ml: Center for Japanese Studies, University of Michigan.

Takatsukasa Seigyoku. 1961. Kuga Seien nikō gyōjitsu. In Jōdoshū nisōshi, ed. Jōdoshū nisōshi hensan iinkai, 98-121. Kyoto: Yoshimuzu Gakuen Kōtō Gakkō. 
Takatsukasa, Seigyoku. 2009. Nagare no mamani: Zenkōji Daihongan Takatsukasa Seigyoku shōnin jiden. Nagano: Shinano Mainichi Shinbunsha.

Takatsukasa, Seigyoku. 2011. Okagesama no inochi o ikiru: gokuraku ōjō e no michishirube. Tokyo: Kōdansha.

Tamayama, Jōgen. 1976. (Shinkan Shōkai) Takatsukasa Seigyoku chō Shinshū Daihongan Edo Aoyama Zenkōji Chikan Shōnin. Nihon Bukkyō Shigaku 11(December): 104-106.

Teramori Kyōzan. 1953. Nisō no sugata. Jōdo 19 (September): 16-17.

The Economist. 2014. Holding Back Half the Nation, March 29. http://www.economist.com/news/briefing/21599763womens-lowly-status-japanese-workplace-has-barely-improved-decades-and-country. Accessed 15 January 2015.

Uno, Kathleen S. 1993. Death of 'good wife, wise mother'? In Postwar Japan as history, ed. Andrew Gordon, $293-322$. Berkeley: University of California Press

Yomiuri Shimbun Newspaper. Retrieved from Yomidasu Rekishikan, Yomiuri Shinbunsha 2009 - present.

Zenkōji Daihongan (ed.). 2008. Kinsei ikō rekidai Zenkōji shōnin yukari no oshina/Collections related to successive Zenkoji shonin since early modern times. Nagano: Daihonzan Zenkōji Daihongan.

Submit your manuscript to a SpringerOpen ${ }^{\circ}$ journal and benefit from:

- Convenient online submission

- Rigorous peer review

- Immediate publication on acceptance

- Open access: articles freely available online

- High visibility within the field

- Retaining the copyright to your article

Submit your next manuscript at $>$ springeropen.com 